fournal of Medical Genetics (1970). 7, 334.

\title{
Mutation Rate in Duchenne Type of Muscular Dystrophy*
}

\author{
DAVID GARDNER-MEDWIN†
}

\section{From the Muscular Dystrophy Laboratories, Newcastle General Hospital, Newcastle upon Tyne}

The mutation rate in the Duchenne type of muscular dystrophy has generally been estimated by the indirect method of Haldane (1935) using his formula for $\mathrm{X}$-linked recessive traits

$$
U=1 / 3(1-f) x
$$

where $U$ is the mutation rate, $f$ the effective fertility of affected males, and $\mathbf{x}$ the incidence of affected individuals in the male population. Since the effective fertility of males with this disorder is zero, the mutation rate amounts to $1 / 3$ of the incidence among males. Estimates on this basis have varied from $4.3 \times 10^{-5}$ (Walton, 1955) to $9.5 \times 10^{-5}$ per gene per generation (Stephens and Tyler, 1951). Perhaps the most satisfactory population study was that of Stevenson (1958) whose figures give a mutation rate of $6.0 \times 10^{-5}$. Morton and Chung (1959) used the technique of segregation analysis of sporadic cases to obtain a figure of $8.9 \times 10^{-5}$, but they appear to have included some cases of the benign $\mathrm{X}$-linked (Becker) type of muscular dystrophy in their calculations, which invalidate the result obtained.

Carrier detection techniques provide a basis for more direct estimation. The serum creatine kinase level is now well established as the most useful index of the carrier state. Results of surveys from many centres show that over-all about $75 \%$ of known carriers can be detected (Walton and GardnerMedwin, 1969). Investigation of large series of mothers of isolated cases of muscular dystrophy shows that relatively few of them are detected as carriers (Thompson, Murphy, and McAlpine, 1967; Gardner-Medwin, 1969). Most of the remainder are presumably the non-carrier mothers of those cases which have arisen by new mutation.

A considerable problem, however, is posed by the possibility that some cases of 'Duchenne' muscular

Received 23 January 1970.

* This study includes material submitted in a thesis for the degree of M.D. at the University of Cambridge.

+ Present address: Department of Neurology, Massachusetts General Hospital, Fruit Street, Boston, Massachusetts, 02114, U.S.A. dystrophy are inherited as an autosomal recessive trait (Lamy and de Grouchy, 1954; Blyth and Pugh, 1959). As a result of a recent review the author believes such cases to be very rare. The reasons can be summarized briefly as follows: (a) proof of the existence of an autosomal recessive childhood dystrophy depends on the discovery of females with the disease. The published reports of such females very rarely give satisfactory histological evidence of the diagnosis, and in view of the recently recognized relatively high incidence of benign spinal muscular atrophy simulating muscular dystrophy (Gardner-Medwin, Hudgson, and Walton, 1967), most of the reported 'female Duchenne' cases may be examples of neurogenir disease. This possibility is strengthened by the fact that secondary myopathic change may occur in chronically denervated muscle and cause serious diagnostic difficulty, whether clinical, enzymological, electromyographic, or histological criteria are used for diagnosis. (b) In a study of cases of muscular dystrophy which began in childhood and predominated in the lower limbs, the absolute prevalence of the disease in a population of 3.3 million in the north of England was males (Duchenne type) 91 , females 2 ; the minimum prevalence of cases of benign spinal muscular atrophy with onset before 12 years was males 12 and females 14 . (c) The 2 females with muscular dystrophy and 3 others referred from elsewhere were compared with the Duchenne cases and were found to have a similar age of onset but slower progression and longer survival; similar clinical features, though asymmetry was commoner in females; lower or similar serum creatine kinase levels in the late stage of the disease (no information was available for females in the early stages); less severe histological abnormalities; and electrocardiograms which lacked the typical features of Duchenne dystrophy (Perloff, de Leon, and O'Doherty, 1966). Two male cases, not diagnosed as of the Duchenne type on clinical grounds, more closely resembled the female cases. Thus it 
appears not only that autosomal cases are rare but that they are usually distinguishable from X-linked cases by appropriate investigation. The possibility of autosomal recessive inheritance in typical cases of Duchenne muscular dystrophy is therefore discounted in the present study.

\section{Methods}

Creatine kinase (CK) assays were performed by the method of Pearce, Pennington, and Walton (1964). Up to March 1969 the results in 34 normal control subjects and 190 female relatives of patients with Duchenne muscular dystrophy were available. The upper limit of normal, calculated as the mean +2 standard deviations of the logarithms of the results in normal subjects, was 75 international units/litre (Gardner-Medwin, 1969). For the purpose of the present study, however, a serum CK level of 67 I.U./litre was chosen as giving the best discrimination between control subjects (among whom the highest observed serum CK level was 67 I.U./litre) and known carriers. The 'known carriers' included 24 women with affected sons and affected brothers or maternal uncles and 11 mothers of 2 or more affected sons without other affected relatives. The detection rate for known carriers was $22 / 35(63 \%)$ and for mothers of isolated cases $15 / 56$. On the assumption that the detection rate for true carriers is the same in the two groups, one would expect $[56-(35 / 22) 15]=32 \cdot 2$ noncarriers among the mothers of isolated cases. This gives a prevalence of new mutants of $57.5 \%$ of the isolated cases. The equivalent figure derived from the data of Thompson et al. (1967) is $49 \%$.

The mutation rate can now be calculated using the number of cases of Duchenne muscular dystrophy ascertained at the Newcastle Regional Neurological Centre for each year of birth from 1949 to 1964 . In earlier years the records are unreliable; in later ones the numbers diminish, presumably because some cases born in these years have not yet been referred. The years 1952 to 1960 inclusive have been chosen as giving the most reliable data (Table I).

The cases included have all been diagnosed as having Duchenne muscular dystrophy by Professor J. N.
TABLE I

\section{NUMBER OF CASES OF DUCHENNE MUSCULAR DYSTROPHY BORN IN REGIONAL HOSPITAL BOARD AREA}

\begin{tabular}{|c|c|c|c|c|}
\hline Year & Isolated & $\begin{array}{c}\text { With } \\
\text { Affected } \\
\text { Brothers }\end{array}$ & $\begin{array}{l}\text { With Other } \\
\text { Affected } \\
\text { Relatives }\end{array}$ & Total \\
\hline $\begin{array}{l}1949 \\
1950 \\
1951 \\
\end{array}$ & $\begin{array}{l}2 \\
5 \\
4 \\
\end{array}$ & $\begin{array}{l}2 \\
2 \\
2 \\
\end{array}$ & $\begin{array}{r}3 \\
1 \\
\end{array}$ & $\begin{array}{l}7 \\
8 \\
6 \\
\end{array}$ \\
\hline $\begin{array}{l}1952 \\
1953 \\
1954 \\
1955 \\
1956 \\
1957 \\
1958 \\
1959 \\
1960 \\
\end{array}$ & $\begin{array}{r}7 \\
6 \\
3 \\
4 \\
5+1 \\
5 \\
3 \\
4 \\
5\end{array}$ & $\begin{array}{l}1 \\
1 \\
4 \\
2 \\
3 \\
2 \\
3 \\
3 \\
2 \\
\end{array}$ & $\begin{array}{l}1 \\
1 \\
1 \\
2 \\
1 \\
2 \\
3 \\
1 \\
1 \\
\end{array}$ & $\begin{array}{r}9 \\
8 \\
8 \\
8 \\
10 \\
9 \\
9 \\
8 \\
8 \\
\end{array}$ \\
\hline $\begin{array}{l}1961 \\
1962 \\
1963 \\
1964 \\
\end{array}$ & $\begin{array}{l}2 \\
3 \\
1\end{array}$ & $\frac{2}{1}$ & $\begin{array}{l}2 \\
1 \\
1 \\
1 \\
\end{array}$ & $\begin{array}{l}6 \\
4 \\
3 \\
1 \\
\end{array}$ \\
\hline $\begin{array}{l}\text { Total for } \\
1952-1960\end{array}$ & $42+1 ?$ & 21 & 13 & 77 \\
\hline
\end{tabular}

Walton during a period when his interest in the disease was widely known and virtually every case in the Newcastle Regional Hospital Board area may be assumed to have been referred for his opinion. All cases now diagnosed as having the Becker type and all females are excluded. The place of birth was not recorded in 7 cases, but in an attempt at complete ascertainment cases cannot be excluded for this reason, and the assumption is made that the possible inclusion of some cases born outside the area is balanced by the emigration before referral of other cases. All cases known or strongly suspected to have been born elsewhere are excluded from the study. In one case born in 1956 and now lost to follow-up the notes imply, but do not state explicitly, that no other member of the family was affected.

The incidence of a disease which is not apparent at birth should be expressed not in relation to live births but to live-born children surviving to the age of ascertainment. Table II shows the live births for the years 1952 to 1960 . The columns headed 'Deaths before 5 years'

TABLE II

POPULATION STATISTICS FOR THE GRO 'NORTHERN AREA'

\begin{tabular}{|c|c|c|c|c|c|c|}
\hline \multicolumn{4}{|c|}{ Total } & \multicolumn{3}{|c|}{ Male } \\
\hline Year & $\begin{array}{c}\text { Live } \\
\text { Births }\end{array}$ & $\begin{array}{l}\text { Deaths } \\
\text { Before } \\
5 \text { years }\end{array}$ & $\begin{array}{c}\text { Surviving } \\
\text { to } \\
5 \text { years } \\
\end{array}$ & $\underset{\text { Births }}{\text { Live }}$ & $\begin{array}{l}\text { Deaths } \\
\text { Before } \\
5 \text { years }\end{array}$ & $\begin{array}{c}\text { Surviving } \\
\text { to } \\
5 \text { years }\end{array}$ \\
\hline $\begin{array}{l}1952 \\
1953 \\
1954 \\
1955 \\
1956 \\
1957 \\
1958 \\
1959 \\
1960 \\
\end{array}$ & $\begin{array}{l}\mathbf{5 3}, 793 \\
54,987 \\
\mathbf{5 3}, 881 \\
\mathbf{5 4}, 088 \\
\mathbf{5 5 , 7 8 2} \\
\mathbf{5 8 , 0 5 8} \\
\mathbf{5 9 , 3 4 4} \\
\mathbf{5 8 , 8 3 2} \\
\mathbf{5 9 , 6 8 4}\end{array}$ & $\begin{array}{l}1959 \\
1831 \\
1900 \\
1682 \\
1778 \\
1860 \\
1820 \\
1812 \\
1732\end{array}$ & $\begin{array}{l}51,830 \\
53,160 \\
51,980 \\
52,400 \\
54,000 \\
56,200 \\
57,520 \\
57,020 \\
57,950\end{array}$ & $\begin{array}{l}27,594 \\
28,282 \\
27,943 \\
27,645 \\
28,664 \\
30,027 \\
30,529 \\
30,501 \\
30,740\end{array}$ & $\begin{array}{r}1106 \\
1041 \\
1067 \\
949 \\
1019 \\
1060 \\
1040 \\
1030 \\
990\end{array}$ & $\begin{array}{l}26,490 \\
27,240 \\
26,880 \\
26,700 \\
27,650 \\
28,970 \\
29,490 \\
29,470 \\
29,750\end{array}$ \\
\hline Total & & & 492,060 & & & 252,640 \\
\hline
\end{tabular}


give the sum of the infant mortality for the subsequent year, together with an estimate of the expected additional mortality between the age of 1 and 5 years (which remains relatively constant from year to year). All the figures are based on the medical statistical tables of the General Register Office (G.R.O.) for the relevant years. Mortality between 5 years and the mean age at ascertainment can be ignored.

A further complication arises because the G.R.O. tables give figures for the 'Northern Area' which differs from the Regional Hospital Board area by the inclusion of the whole instead of only part of Westmorland and of the North Riding of Yorkshire. The live births in the Regional Hospital Board Area were however also recorded in the years 1963 to 1967, and throughout this later period the ratio of numbers of live births in the Regional Hospital Board area to those in the whole Northern Area remained constant at 0.935. The assumption has been made that this ratio applied also between 1952 and 1960 and that the mortality rate in the two areas was the same. The figure for total numbers of live-born children surviving to age 5 in the Northern Area has therefore been multiplied by 0.935 . This gives a total population of children surviving to the age of 5 years who were born in the Newcastle Regional Hospital Board area in the years 1952-1960 inclusive of 459,500, of whom 236,200 were males.

\section{Results}

The total number of ascertained cases of Duchenne muscular dystrophy born in the region in the nineyear period was 77 , of which $43(56 \%)$ or possibly 42 were isolated cases. This gives an incidence of 16.8 cases per 100,000 children of both sexes attaining the age of 5 (32.6 per 100,000 males).

Using Haldane's formula the mutation rate is $10.9 \times 10^{-5}$ per gene per generation.

Using the relatively direct method based on carrier detection, where $U=$ mutation rate, $J=$ number of isolated cases born in the period, $R=$ the proportion of isolated cases whose mothers are noncarriers, and $T=$ number of males born in the period who attained the age of 5 , then

$$
\mathrm{U}=\frac{\mathrm{JR}}{\mathrm{T}}=\frac{43 \times 0.575}{236,200}=10.5 \times 10^{-5} \text {. }
$$

This figure is expressed as mutations per male live birth or as mutations per gene per generation. If the mutation rate is equal in ovum and sperm then there should be twice as many new mutant carrier females in the population (each with two $\mathrm{X}$ chromosomes) as new mutant affected males (with one $\mathrm{X}$ chromosome).

\section{Discussion}

The method is attractively direct, but it depends for its accuracy upon the reliability of ascertainment of isolated cases and the uniformity of results of $\Omega$ serum creatine kinase estimations. Some diffi- $\frac{\mathbb{D}}{\overparen{D}}$ culties over ascertainment have been discussed; the $\stackrel{\oplus}{-}$ error at the most can hardly exceed $10 \%$. The iso- $\overrightarrow{\bar{B}}$ lated cases upon whose mothers the serum $\mathrm{CK}+\frac{7}{7}$ studies were performed and those which appear in Table I were not always the same. But only 8 of the 1952-1960 series are not in the serum CK series, and there is no reason to expect the two groups to differ significantly. Nor is there any obvious source of error or bias which might invali- $\vec{\circ}$ date the results of the $\mathrm{CK}$ studies.

The figure of $32.6 \times 10^{-5}$ for the incidence of the disease among males is higher than in previous studies where the following figures were obtained: $28.6 \times 10^{-5}$ (Stephens and Tyler, 1951), 13.0 × 10 (Walton, 1955), $18.2 \times 10^{-5}$ (Stevenson, 1958),

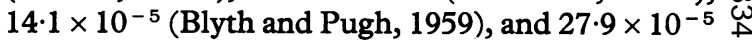
(Morton and Chung, 1959). Falsely high ascer- 을 tainment is unlikely, but even after exclusion of the 7 cases whose birth place was uncertain the incidence is $29.6 \times 10^{-5}$. Incomplete ascertainment is more probable and $32.6 \times 10^{-5}$ should perhaps be considered as a minimum figure.

The mutation rate based on carrier detection agrees closely with that obtained by the Haldane method. The latter method assumes norman fertility in carrier females; yet most women who know or fear that they may bear a dystrophic child purposely restrict their fertility. Some evidence for this is shown in Table I where the proportion of cases where the mothers are definite or probable carriers is relatively low. The expected proportion of sporadic cases is $\mathrm{mu} /(2 \mathrm{u}+\mathrm{v})$ for a sex-linked gene where $\mathrm{m}=$ the selection coefficient against affected males ( 1 in this disease) and $u$ and $v$ are the mutation rates in ovum and sperm, respectively (Morton and Chung, 1959). If $\mathrm{u}$ and $\mathrm{v}$ are equal the frequency should be 0.33 . In the present series it is $43 / 77=0.56$, a figure that strongly suggests that genetic advice is beginning to have some effect upon the incidence of the disease. One might therefore expect the Haldane method to give a falsely low result. The actual close agreement in the mutation rates calculated by this method and the carrier-detection method (which is independent of the fertility of carriers) is difficult to explain.

The 21 cases with affected brothers in Table I included 7 first-affected, 12 second-affected, and 2 third-affected boys. Their mothers were clearly carriers. The incidence of first-affected boys born in the population in the 9 years was therefore $43+$ $7=50$, of whom about $0.575 \times 43(=25)$ were new mutants and about $7+43(1-0.575)=25$ were born to unwitting (and probably mostly mutant) 
carriers. In the same period the remaining 27 affected boys were born to mothers who could have been suspected to be carriers, and their births alone could theoretically have been prevented by prompt diagnosis and genetic counselling.

\section{Summary}

The incidence of Duchenne muscular dystrophy in North Eastern England between 1952 and 1960 was about 32.6 per 100,000 males surviving to the age of 5 years. The mutation rate calculated by a method founded upon carrier detection was about $10.5 \times 10^{-5}$ per gene per generation. Some evidence suggesting that autosomal recessive inheritance in 'Duchenne' cases is rare is briefly summarized. Only about one-third of cases of this disease are theoretically preventable by ideal genetic counselling.

I am very grateful to Professor J. N. Walton and Dr. D. F. Roberts for valuable advice and Mrs. Y. Chisholm for typing the manuscript.

\section{REFBRENCES}

Blyth, H., and Pugh, R. J. (1959). Muscular dystrophy in childhood; the genetic aspect. A field study in the Leeds region of clinical types and their inheritance. Annals of Human Genetics, 23, 127-163.
Gardner-Medwin, D. (1969). The use of electromyography for carrier detection. Proceedings of the International Congress on Muscle Diseases, Milan. In the press.

, Hudgson, P., and Walton, J. N. (1967). Benign spinal muscular atrophy arising in childhood and adolescence. fournal of the Neurological Sciences, 5, 121-158.

Haldane, J. B. S. (1935). The rate of spontaneous mutation of a human gene. fournal of Genetics, 31, 317-326.

Lamy, M., and de Grouchy, J. (1954). L'hérédité de la myopathie (formes basses). Fournal de Génétique Humaine, 3, 219-261.

Morton, N. E., and Chung, C. S. (1959). Formal genetics of muscular dystrophy. American fournal of Human Genetics, 11, 360-379.

Pearce, J. M. S., Pennington, R. J., and Walton, J. N. (1964). Serum enzyme studies in muscle disease. Part I. Variations in serum creatine kinase activity in normal individuals. fournal of Neurology, Neurosurgery and Psychiatry, 27, 1-4.

Perloff, J. K., de Leon, A. C. Jr., and O'Doherty, D. (1966). The cardiomyopathy of progressive muscular dystrophy. Circulation, 33, 625-648.

Stephens, F. E., and Tyler, F. H. (1951). Studies in disorders of muscle. V. The inheritance of childhood progressive muscular dystrophy in 33 kindreds. American fournal of Human Genetics, 3, 111-125.

Stevenson, A. C. (1958). Muscular dystrophy in Northern Ireland. IV. Some additional data. Annals of Human Genetics, 22, 231234.

Thompson, M. W., Murphy, E. G., and McAlpine, P. J. (1967). An assessment of the creatine kinase test in the detection of carriers of Duchenne muscular dystrophy. Fournal of Pediatrics, 71, 82-93.

Walton, J. N. (1955). On the inheritance of muscular dystrophy. With a note on blood groups, by R. R. Race and a note on colour vision and linkage studies, by Ursula Philip. Annals of Human Genetics, 20, 1-38.

, and Gardner-Medwin, D. (1969). Progressive muscular dystrophy and the myotonic disorders. In Disorders of Voluntary Muscle, 2nd ed. Ed. by J. N. Walton. Churchill, London. 